\title{
A RESEARCH UPON THE SUSTAINABLE NATURE-BASED TOURISM: CASE OF WESTERN BLACK SEA REGION OF TURKEY
}

\author{
Mehmet Keskin ${ }^{1}$ \\ Orhan Akova ${ }^{2}$
}

\begin{abstract}
Natural and cultural assets are among the most important resources that generate the tourism supply. Tourism trends are changing rapidly from mass tourism to alternative tourism and in recent years there have been significant initiatives concerning sustainable and environmentally sensitive tourism in Turkey. The Western Black Sea Region has a great potantial for nature-based tourism with its biodiversity, unspoiled nature, lakes, waterfalls, National Parks and Protected Areas. National Parks, Nature Parks, Natural Areas are under the responsibility of the Ministry of Water Affairs and Forestry in Turkey. Many types of tourism and activities such as ecotourism, nature tourism, hunting, trekking are carried out under the control of the General Directorate of Nature Conservation and National Parks. The aim of this study is to evaluate the strategy of General Directorate of Nature Conservation and National Parks for sustainable nature-based tourism and to reveal sustainable nature-based tourism strategy for the Western Black Sea Region. For this purpose, "Master Plan of Nature-Based Tourism of Sinop " examined by document analysis method which was prepared by 10th Regional Directorate for the Province of Sinop. And also In-depth interviews conducted with the 10.th Regional Director of Forestry about their activities and strategies about sustaniable nature-based tourism. Findings show that Forestry has many activities and practices sush as "Enhancing Forest Protected Areas Management System",and "DisabledFriendly Accessible National Park Project”.
\end{abstract}

Keywords: Sustainable tourism, Nature-based tourism, General Directorate of Nature Conservation and National Parks, Western Black Sea Region,

\section{INTRODUCTION}

Tourism has been expanding and diversifying so fast that it becomes one of the largest and fastest growing economic sectors in the world over the past six decades. According to United Nations World Tourism Organization, with over 1.1 billion tourists taking an international trip every year, tourism continues to be an unstoppable force and a key driver of the global economic recovery. Yet tourism's record growth is not merely absolute numbers. Tourism's continued progress and expansion represents an effective solution for many of the world's greatest challenges. Indeed, few sectors are as strategically positioned as tourism to contribute decisively to job creation, poverty alleviation, environmental protection (UNWTO, 2015: 2). Many new destinations are introduced to get more share from tourism benefits that are challenging the traditional tourism destinations of Europe and North America (UNWTO 2012:2). As tourism industry develops implementation of sustainable tourism principles has become increasingly important for tourism businesses, tourists and local communities (Bride et al., 2010; Curto, 2006; Gursoy and Rutherford, 2004).

Especially after the Second World War, tourism industry developed in the form of mass tourism and this has led to several negative impact on the natural and cultural environment.

\footnotetext{
${ }^{1}$ Lecturer, Department of Tourism and Hotel Management, Gerze Vacational School, Sinop University, Turkey.

${ }^{2}$ Associate Professor, Department of Tourism Management, Economics Faculty, Istanbul University, Turkey.
} 
Negative factors can lead to the deterioration of the environment and resulting to lose of the attractiveness of the region. Negative affects caused by the mass tourism on the environment, changing expectations of tourists and number of different tourism seeking and wanting to have high levels of interaction with nature (Kerr, 1991: 248). Since the beginning of humanity people intertwined with nature.Today's urban people tends to move away from a variety of adverse effects such as traffic, pollution, noise, nature and natural longing. These trends has revealed the use of sustainable tourism concepts, such as agrotourism, alternative tourism, ecotourism, soft tourism, slow tourism, rural tourism etc.

Turkey has several unique opportunities for different types of tourism compiled under the category of alternative tourism however, it is yet hard to say that this potential is used in a rational manner. In order to wiser use of natural, cultural, historical and geographical assets that Turkey has, some strategic plan made bygovernment.In Tourism Strategy of Turkey-2023 (Culture and Tourism Ministry,2007) instead of the mass concentration of the Mediterranean and Agean Coastal areas its aimed to the tourism spread to the whole year and to all regions by diversifying tourism activities. Additionally in Turkey Tourism 2023 Strategy Action Plan 2007-2013 (2007), sustainable tourism is referred as one of the tourism development principles. As it is pointed out in the tourism vision of Turkey, defined by Turkish Ministry of Culture and Tourism, tourism sector should be handled as one of the leading sectors which contribute to regional development. Therefore, in this Action Plan various tourism development corridors designated in relation to the features of regions with the purpose of differentiating tourism development potentials, so that; maximization of tourism benefits will be maintained through attracting different tourist profiles. Western Black Sea Region declared as ecotourism oriented zone.

Forests and other natural areas are among the most popular ecotourism destination. Therefore it is important to adopt a sustaniable development approach in the management of natural areas. The Western Black Sea Region has a great potantial for nature-based tourism with its biodiversity, unspoiled nature, lakes, waterfalls, National Parks and Protected Areas. National Parks, Nature Parks, Natural Areas are under the responsibility of the Ministry of Water Affairs and Forestry in Turkey.And the Black Sea region where forest vegetation has a very important place in Turkey with biodiversity and natural protected areas. A wide variety of tourism activities in natural areas located in Western Black Sea Region being performed and maintenance of these areas, in order to protect nature conservation and national parks are maintained by the regional offices. The aim of this study is to examine the sustainable nature conservation and national parks for nature tourism district directorate of operations.

\section{SUSTANIABLE NATURE-BASED TOURISM}

In the 1970s and 1980s, environmental issues (e.g., air and water pollution and endangered species) sparked public concern and government intervention in the United States and Europe (Ceron \& Dubois, 2003; Choi \& Sirakaya, 2005; Huayhuaca, Cottrell, Raadik, \& Gradl, 2010; Liu, 2003)During this same period, sustainability discussions attempted to provide solutions to the most pressing environmental issues (Butler, 1999; Liu, 2003). Although consensus on the definition of sustainability had not yet been reached (Valentin \& Spangenberg, 2000), the Brundtland Report asserted that sustainable development "meets the needs of present generations without compromising the ability of future generations to meet their own needs" (World Commission on Environment and Development, 1987, Conclusion section, para. 1). The 1992 Earth Summit in Rio de 
Janeiro, Brazil expanded on this definition by creating principles for sustainable development (Cottrell, van der Duim, Ankersmid, \& Kelder, 2004) that operationalize the concept of sustainability and its application to development. With human societies moving into the 21 st century, sustainability and sustainable development have become increasingly important, and the concept of sustainable development has been widely used as an organizing framework in political agendas (Dymond, 1997; Cottrell, Vaske \& Roemer, 2013).).

As the tourism industry continues to grow, applying sustainable development principles becomes increasingly important for tourism stakeholders (Brida et al., 2010; Curto, 2006; Gursoy \&Rutherford, 2004). Over the last few decades, expansive and uncontrolled tourism development is accompanied by manyundesirable environmental, social and cultural implications that impose the need for tourism to be under the concept of sustainable development. Sustainability of tourism development depends on environmental opportunities to ensure a stable and lasting basis.

Conventional mass tourism, which is the most common form of tourism development, has generally accepted as an unsustainable form of tourism because of it is being opposite to sustainable development principles and objectives. Therefore, the concerns about tourism development have risen up. The need of approaching tourism in sustainable development context has become one of the main concerns of tourism theorists and practitioners since 1990s'. As Hunter (1997) indicated, the paradigm of conventional tourism development has substantially shifted to a new way of development, which is, namely, sustainable tourism development.

The first definition of sustainable tourism has been declared by the United Nation World Tourism Organization in 1996: "tourism which leads to management of all areas, in such a way, that the economic, social and environmental needs are being fulfilled with the cultural integration, ecological processes, biodiversity and supporting the development of societies". In addition, with reference to the concept of sustainable development, be considered not only in relation to specific categories of tourist activity, but also in relation to the framework for creating all forms of tourism, including mass tourism and its types. The concept of sustainable development based on environmental, social and economic grounds, which are also basis for sustainable tourism.

Some of the sustainable tourism activities should be characterized by (Buckley 2009):

- Optimal use of natural resources, proper environmental management processes and efforts to preserve, biodiversity,

- Respect for socio-cultural attitudes of the local community, the preservation of cultural and traditional values, as well as taking action to intercultural understanding and tolerance,

- Ensuring real and lasting economic processes enabling to benefit society by all actors involved, includingstable employment and income-earning opportunities.

The natural environment has long been utilized as are source for tourism development (Maher,2012). Particularly,tourists are attracted by breathtaking landscapes in protected areass. Nature-based tourism is considered an important component of sustainable tourism development, particularly in remote areas. However, "nature-based tourism" is a controversial term with no coherent definition(Goodwin, 1996). An early explication of Ceballos-Lascurain (1996) describes nature-based tourism's direct dependency on natural resources in a relatively undeveloped state, including scenery, water features, vegetation, andwildlife. Since the late 1980s, nature-based tourism and ecotourism, which requires an explicit contribution to nature conservation(Boo,1990; Job \& Paesler, 2013), The concept of nature based tourism is broad and encompassing. It is therefore unsurprising that 
establishing an exact definition has proved to be both difficult and is a source of ongoing debate among researchers (Fennell, 2000; Higgings, 1996; Mehmetoglu, 2007). Despite this, particular elements are common among many of the definitions, namely that learning, recreation and adventure take place in natural surroundings (Laarman \& Durst, 1987; Laarman \& Gregersen, 1996; Wurzinger \& Johansson, 2006).

Nature based tourism is frequently used synonymously with other terms such as sustainable tourism, green, rural, alternative, adventure and responsible tourism (Higgings, 1996; Luzar et al., 1998; Priskin, 2001; Roberts \& Hall, 2004; Weiler \& Hall, 1992). Valentine and Cassells (1991)have argued that nature based tourism experiences (activities)can be classified into three distinct types: experiences dependenton nature, experiences enhanced by nature, and experiences inwhich the natural settings are supplementary.In this study, we define nature based tourism astourism activities in which the focus is upon activities that takeplace in a nature area and where the tourism activities are directlyor indirectly dependent on the natural environment.

There are many studies in the literature related to sustainable tourism that has become an important issue for tourist destinations. Some studies are available in a book form such as; Sustainable tourism (Mowforth and Munt, 2003), marketing approach to sustainable tourism (Middleton and Rebecca 1998) and some studies examined the sustainable tourism by the perspectives of tourists (Beguma, et al., 2014), local governments (Selvi and Sahin, 2012; Delgado and Palomeque, 2014), local community (Cottrell, et al., 2013). Howewer there is not enough studies about the role and plans of the forestry. Therefore, in this study we determine the activities and strategy of General Directorate of National Parks and Nature Conservationrelated to sustaniable nature based tourism

\section{NATURE CONSERVATION AND NATIONAL PARKS GENERAL DIRECTORATE' RESPONSIBILITIES}

General Directorate of Nature Conservation and National Parksresponsible for managing the national parks, nature parks, natural monuments and other nature conservation area. Nature Conservation and National Parks some substances contained in the regulations relating to the duties of the General Directorate as follows:

- National parks, nature parks, natural monuments, separation of nature conservation areas and adequate recreation ares, conservation, planning,organization, development, promotion, management, operation and carry out activities releated to processing by.

- $\quad$ To make open space arrangement, landscaping projects, infrastructure project according to the changing and developing conditions, make revision work that would be needed .

- To carry out the implementation plan for nature based tourism activities at the national parks, nature parks, natural monuments and in accordance with the nature conservation areas.

- Develop policies for the protection of nature, related to the sustainable use of biological resources, protection of biodiversity and landscape strategy, criteria and principles of doing business and operations 
General Directorate of Nature Conservation and National Parks (DCM) national parks, nature parks, natural monuments, is a general manager responsible for managing the area more attractive compared to other woods in terms of ecotourism as nature protection areas. This field of general manager responsibility carries more opportunities for ecotourism but in terms of the potential adverse effects of ecotourism plays a greater risk. As can be seen in action in the National Forestry Program 109, coordination and leadership role in ecotourism belongs to the General Directorate of Nature Protection and National Parks. This mandate is a mandate of the nature of the business should be considered correct. Indeed, tourism, eco-tourism, the industry leader in the recreation issue should be the General Directorate of DCM.

The sustainable use of natural and cultural assets is increasing the need for ecologically based land use planning. This requirement is increased by the ongoing pressures on the natural and cultural environment (land speculation, population growth, environmental issues, legal inadequacies and gaps, improper resource management, etc.) It has become a necessity to the cause. Determining the promotion and use of important natural and cultural areas of planning criteria, with tourism and recreational potential will increase the attractiveness of this region. Many of the tourism and recreational activities take place in rural areas. Recreation plan for the development of rural areas can provide opportunities for the economic development of rural areas (Yesil, 2010).

Turkey has many natural and that constitutes an important and rich in potential for alternative tourism and recreation and cultural resource values have the opportunity. However, this potential due to lack of proper planning and rational approach can not be used effectively for nature based tourism and conservation. In this study we examined the activity and plans of the General Directorate of Nature Conservation and National Parks for the environmental protection and nature-based tourism.

\section{METHODOLOGY}

Research data were collected by using document analysis method of qualitative research techniques. Document analysis, analysis of written materials contain information about the subject of research (Yildirim and Simsek, 2005: 188-189). Document analysis is a technique for using the pre-existing or occurring materials (Scott and Morrison, 2005; Ozkul and Demir, 2012). For this context "Nature Tourism Master Plan" was examined which prepared by 10th. Regional Directorate of Forestry for the five province of Western Black Sea Region of Turkey. Also qualitative research methods, interview, used for data collection. In this context semi-structured questionnaire form used and interview was conducted with Oguz BAYAZIT, 10th Regional Director of Forestry.

Forestry and Water Affairs Ministry has 15 Regional Directorates and 81 Provincial Directorates. 10th Regional Directorate is responsible for 5 provinces (Bartin, Karabuk, Kastamonu, Sinop and Zonguldak) of Western Black Sea Region of Turkey. There are 2 national parks 12 natural parks and 5 nature monument in the region (http://sinop.ormansu.gov.tr/). Sinop is headquarter of regional diroctorate so that was chosen as the sample frame forthis study. 


\section{FINDINGS}

\section{Strategies for the Development of Nature Tourism at the National Parks, Nature Parks and Similar Fields}

Tab.1. National parks, nature parks and similar fields of Sinop

\begin{tabular}{|c|c|}
\hline Name & District \\
\hline Hamsilos Natural Park & Sinop \\
\hline Tatlıca Waterfall Nature Park & Erfelek \\
\hline Topalçam Nature Park & Boyabat \\
\hline Basalt Cliffs Natural Monument & Boyabat \\
\hline Çatak Kanyonu Tabiat Park1 (bid field) & Türkeli \\
\hline Çangal Tabiat Park1 (bid field) & Ayancık \\
\hline Akgöl Tabiat Park1 & Ayancık \\
\hline Sarikum Nature Reserve & Sinop \\
\hline Bozburun Wildlife Development Field & Sinop \\
\hline
\end{tabular}

According to finding at Sinop Nature Tourism Master Plan some of the strategies for nature parks and similar fields (Tab. 1.) are as follows:

- Natural parks and other tourism assets of Sinop has not yet reached the carrying capacity Therefore, with marketing activities and other arrangements can be attract more visitors.

- In order to ensure the drinking, eating and navigation of the visitors, convenience facilities such as restaruant, cafe and walking path and bike path need to be done at Hamsilos Natural Park

- Sarikum Nature Reserve should be converted to a nature park and this area should be planned as Outdoor Nature Education Center. This nature education should be planned for the summer and winter periods with individual education programs. Implementation of nature will bring additional mobility training is foreseen in nature tourism.

- Erfelek Tatlica Falls Nature Park is cuitable for picnic and trekking concept. In addition, visitors should be provided to leave more income for the local people by adding their gastronomic value of Erfelek County. Erfelek County natural products such as walnut, pickles, nuts, molasses, dried vegetables, dried fruits, canned foods, jam, etc. assessment of the tourism market will be additional value-added to local community.

- It is necessary to be done a Stone Museum at the Basalt Cliffs Natural Monument to attraction of more visitors.

- Catak Canyon in Turkeli Town and Cangal Forest in Ayancik Town should be registered as a Natural Park for beter conservation and planned nature tourism activitity. At Cangal Forest and Akgol Lake Youth camps, summer schools should be made here. The old plant was demolished obsolete construction of new facilities will be provided.

- Sinop has great potantial for nature-based tourism with its wildlife observation fields, hiking, mountain haking, nature and authentic villages trips, highlands etc. 
if deemed necessary, field development plans and plan changes should be done to made beter facilities.

\section{Strategies for the Geological Formations and Waterfalls}

Tab. 2. Cave, Canyons and Waterfalls of Province of Sinop

\begin{tabular}{|l|l|}
\hline Caves & District \\
\hline Inaltı Cave & Ayancık \\
\hline Buzluk Cave & Durağan \\
\hline Canyons & \\
\hline Inaltı Canyon & Ayancık \\
\hline Catak Canyon & Turkeli \\
\hline Waterfalls & \\
\hline Tatlica Waterfalls & Erfelek \\
\hline Poyracik Waterfalls & Gerze \\
\hline Sorgun Waterfalls & Gerze \\
\hline
\end{tabular}

In the same document strategic decisions for the development of nature-based tourism for the canyons, caves and waterfalls value (Tab. 2.) are as follows:

- In the use of the cave, attention should be paid to ecological sustainability and necessary measures must be taken to prevent damage.

- Canyons in the area should be mapped, walk and vehicle road should be detailed and walkways and marking deficiencies to be remedied.

- In order to promotion of all karstic value and to eliminate the lack of accommodation and other infrastructure facilities cooperation should be made with the Provincial Culture and Tourism Directorate.

- For the rural development purposes and to benefit from tourism income of the work should be done in collaboration with other institutions.

\section{Activities and Strategic Plans of 10th Regional Director of Forestry for Sustaniable Nature- Based Tourism}

Since the aim of the study is to understand and reveal the activities and plans of Regional Directorate of Forestry on sustaniable nature-based tourism in depth, an interview was conducted on May 2015. The interview was recorded and fully transcribed in order to guarantee rich data. The interviews were based on a semi-structured framework, which allowed rather flexible conversations to take place while stil ensuring that the main issues were discussed. Accordingly, open-ended questions were used, covering topics such as; meaning of sustaniable tourism, what shoulld be done to ensure the sustainability of natural areas, The current situation in terms of sustainability of the destinations of Sinop, Activities about nature-based tourism as Regional Directorate of Nature Conservation and National Parks and what are the strategies about sustainable nature-basd tourism. Following part contain response of Oguz BEYAZIT who is the 10. Regional Director of Forestry. 


\subsection{Meaning of sustaniable nature tourism and needs to be done to ensure the sustainability of natural areas?}

Sustainable tourism has emerged in response to the increasingly negative impactsof the tourism in the nature of destination. Sustainable nature tourism is sensitive tourism to the natural environment. In order to sustainability of the natural environment, there should no interference with nature nothing must be left to nature and noting should be taken from the nature by the visitors. Visitors and locals of the natural areas, should be informed about the deterioration of naturalness. While investment structure, naturalness of nature must be protected. The carrying capacity of the natural areas do not exceed for commercial considerations.

\subsection{The Current situation in terms of sustainability of the destinations of Sinop}

Despite cultural values, unique natural beauties such as Hamsilos Bay, Akliman, Erfelek Waterfalls, rich vegatation and biodiversity there is not enough visitors to destination of Sinop. So natural areas in the region have not yet reached the carrying capacity. visitors to our region are concentrated in such a short period is 2-3 months during the summer and and the vast majority of these visitors are locals who residing in other cities. Another issue related to region most of the tourist come with daily tour or stay only a night. To generate more revenue from tourism for the regional development and local economy. Also efforts should be made to extend the length of stay of those visitors.

\subsection{Activities and practices as Regional Directorate of Nature Conservation and National Parks on sustainability of nature tourism.}

General Directorate of Nature Conservation and National Parks is the most important guarantee in country's biodiversity, nature and management of protected areas. Our region in Western Black Sea Region has two national parks, two nature conservation area and 12 nature parks within many nature tourism sources. As Regional Directorate with our Provincial Directorates, national and international various stakeholders we are pursuing a number of projects for the development of a number of protected areas for nature tourism. Some of our projects are;

- A project by the Turkish Ministry of Forestry and Water Affairs, an IUCN (International Union for Conservation of Nature) Member, carried out in Küre Mountains National Park, was chosen as best practice on sustainable development and green economy. The project "Enhancing Forest Protected Areas Management System" implemented in Küre Mountains National Park aims to improve the effectiveness of the management of Turkey's forests in the National System of Protected Areas. The project activities have resulted in improved protection for the unique wilderness of the site and effective participation of local people in nature conservation activities. The project has succeeded in setting up a conservation model for the National Park, for sustainable development and tourism, and the green economy. This model has become exemplary for other forest hotspots in Turkey and the National System of Protected Areas (http://www.iucn.org/). 
- "Disabled Accessible National Park Project" is another project for Küre Mountain National Park. 1400 meters on hiking trails will be designed for the disabled and observation deck will be made of the about 500 meters on the Catak canyon.

- Kocagöz Mansion in Küre Mountain National Park district in Ulus Town of Bartin Province restoring byProvincial Directorates and it will be used as center of presentation and ethnography museum.

- Our Regional Regional Directorate has cooperation with universities of the region for natureconservation. In this context, Provincial Directorates holding meetings, workshops, symposium and conference. For example, Biodiversity Panel for Sustainable Development was held with Kastamonu University and bio antitrafficking seminar was held in Bartin University.

- For the Province of Sinop, some of the prectices for Erfelek Waterfalls and Hamsilos, which are among the most visited places in the region, environmental and landscape arrangements projects are conducted. Walkways and parkingarrangement and garbage container are part of our activities for the nature tourism in Sinop.

\subsection{Strategies for sustainable nature-based tourism of Sinop}

As we declared in Nature Tourism Master Plan of Sinop, we have strategies about development, marketing, visitors management, monitoring and evaluation topic. Some of our strateies for sustaniable nature tourism are as follows:

- Sustainable nature tourism products, in the development process without damage with local culture, local environment and society should be considered in harmony.

- In areas with a high potential for nature tourism should be considered as a tool for local development

- Destination-focused promotion and marketing of natural areas can be in national and international areas.

- $\quad$ protection policies for natural areas and visitor management criteria should identified thuseffective management must be provided with taking into account the expectations of visitors and local people.

\section{CONCLUSION AND DISCUSSION}

In recent years there has been a rapid growth in nature-based tourism. Tourism in nature conservation areas requires appropriate management and more sensitivity to nature in order to minimize the adverse effect of touristic activities. This study aimed, through an explorative approach, to understand how nature-based tourism management perceive as protector of natural areas and what kind ofstrategies and activities they are currently using. Theresults of this study show that forestry as nature-based tourism management operating many Project in order to protect nature and sustainability of nature tourism. 
Province of Sinop in Western Black Sea Region of Turkey has many natural assets for tourism and these areas are under the carriying capacity. In order to Protection of Nature Tourism application of social structure, provided that the economic benefits to local people, to be implemented as ecological sustainability benefits and this will be provided social benefits. Nature Tourism sustainability and efficiency of the public to enrich the provincial level, associations, academics and university staff about the subject take place under the same roof as the advisory body of sector stakeholders.

\section{REFERENCES}

Midleton, V. T. and Hawkins, R.(1998), "Sustainable Tourism: A Marketing Perspective Heinemann Linacre House", Jordan Hill, Oxford.

Mowforth, M and Munt, I.(2003), "Tourism and Sustainability, Development and New Tourism in the Third World", 2nd.ed. Routledge, Taylor ana Francis Group, New York.

Scott, D and Morrison, M. (2005). Key ideas in educational research. London: Continuum International Publishing

Weiler, B., \& Hall, C. M. (1992). Special interest tourism. London: Belhaven Press

Yıldırım, A and Simsek, H. (2005). Sosyal Bilimlerde Nitel Araştırma Yöntemleri, Seçkin Kitapevi, Ankara

Beguma, H; Alam, F. and Sahazali, N. (2014) Tourist's perceptions towards the role of stakeholders in sustainable Tourism Procedia - Social and Behavioral

Sciences 144, 313-321.

Brida, J. G., Osti, L., \& Barquet, A. (2010). Segmenting resident perceptions towards tourism - A cluster analysis with a multinomial logit model of a mountain community. International Journal of Tourism Research, 12, 591-602.

Buckley, R. (2006). Adventure tourism products: price, duration, size, skill, remoteness. Tourism Management, 28(6), 1428-1443.

Butler, R. W. (1999). Sustainable tourism: A state-of-the art review. Tourism Geographies, 1(1), 7-25..

Ceron, J., \& Dubois, G. (2003). Tourism and sustainable development indicators: The gap between theoretical demands and practical achievement. Current Issues in Tourism, 6(1), 54-75.

Choi, H. C., \& Sirakaya, E. (2005). Measuring residents' attitude toward sustainable tourism: Development of sustainable tourism attitude scale. Journal of Travel Research, 43(4), 380-394.

Cottrell, S, P.; Vaske, J, J and Roemer, J, M. (2013) Resident satisfaction with sustainable tourism: The case of Frankenwald Nature Park, Germany, Tourism Management

Perspectives 8 (2013) 42-48.

Curto, J. (2006). Resident perceptions of tourism in rapidly growing mountain tourism destinations. Waterloo: University of Waterloo.

Dymond, S. J. (1997). Indicators of sustainable tourisminNewZealand:A local government perspective. Journal of Sustainable Tourism, 5(4), 279-293.

Fennell, D. A. (2000). What's in a name? Conceptualizing natural resource-based tourism. Tourism Recreation Research, 25(1), 97e100.

Goodwin, H.(1996).Inpursuitofecotourism. BiodiversityandConservation, 5(3), 277-291

Higgings, B. R. (1996). The global structure of the nature tourism industry: ecotourists, tour operators, and local businesses. Journal of Travel Research, 35 (2), 11-18 
Gursoy, D., \& Rutherford, D. G. (2004). Host attitudes toward tourism: An improved structural model. Annals of Tourism Research, 31(3), 495-516

Hunter, C., 1997. Sustainable tourism as an adaptive paradigm. Annals of Tourism Research, 24 (4): 850-867.

Johansson, M. (2006). Environmental concern and knowledge of ecotourism among three groups of Swedish tourists. Journal of Travel Research, 45(11), 217e226

Kerr, J. (1991). Making dollars and sense out of ecotourism/nature tourism. 1st International Conference in Ecotourism, Brisbane

Laarman, J. G., \& Gregersen, H. M. (1996). Pricing policy in nature-based tourism. Tourism Management, 17(4), $247 \mathrm{e} 254$.

Liu, Z. (2003). Sustainable tourism development: A critique. Journal of Sustainable Tourism, 11(6), 459-475.

Valentin, A., \& Spangenberg, J. H. (2000). A guide to community sustainability indicators. Environmental Impact Assessment Review, 20(3), 381-392.

Mehmetoglu, M. (2007). Typologising nature-based tourists by activity e theoretical and practical implications. Tourism Management, 28(3), 651-660.

Ozkul, E and Demirer, D. (2012). Şehirlerin Turistik Markalaşmasında Kalkınma Ajaslarının Rolü, Bölge Planları Üzerine Bir Doküman İncelemesi. İşletme Araştırmaları Dergisi. 4/4, 157-181

Priskin, J. (2001). Assessment of natural resources for nature-based tourism: the case of the central coast region of Western Australia. Tourism Management, 22 (6), 637-648.

Selvi, M. S. and Sahin, S. (2012). Yerel Yönetimler Perspektifinden Sürdürülebilir Turizm: Batı Karadeniz Bölgesi Örneği, Uluslararası Sosyal ve Ekonomik Bilimler Dergisi, 2 (2): 23-36..

Weiler, B., \& Hall, C. M. (1992). Special interest tourism. London: Belhaven Press Valentine, P. S., \& Cassells

Wurzinger, S., \& Johansson, M. (2006). Environmental concern and knowledge of ecotourism among three groups of Swedish tourists. Journal of Travel Research, 45(11), 217-226.

http://bolge10.ormansu.gov.tr/10bolge/Files/DO\%C4\%9EA\%20TUR\%C4\%B0ZM\%C4\%B 0\%20MASTER\%20PLANLARI/SINOP\%20ILI\%20DOGA\%20TURIZMI\%20MASTER\%20 PLANI.pdfsflang $=\operatorname{tr}(04.05 .2015)$

http://www.iucn.org/knowledge/focus/shaking_things_up_in_rio/?10124/National-Parkbest-practice-to-represent-Turkey-at-Rio20 (06.08.2015)

http://www2.unwto.org/annualreport2014 (01.08.2015) 